\title{
Corrigendum: Salvinorin A, a kappa-opioid receptor agonist hallucinogen: pharmacology and potential template for novel pharmacotherapeutic agents in neuropsychiatric disorders
}

\author{
Eduardo R. Butelman * and Mary Jeanne Kreek \\ Laboratory on the Biology of Addictive Diseases, The Rockefeller University, New York, NY, USA
}

Keywords: kappa-opioid receptor, dynorphins, salvinorin A, Salvia divinorum, depression, addiction

\section{A corrigendum on}

Salvinorin A, a kappa-opioid receptor agonist hallucinogen: pharmacology and potential template for novel pharmacotherapeutic agents in neuropsychiatric disorders

by Butelman, E. R., and Kreek, M. J. (2015) Front. Pharmacol. 6:190. doi: 10.3389/fphar.2015.00190

\section{OPEN ACCESS}

Edited and reviewed by: George Panagis,

University of Crete, Greece

*Correspondence:

Eduardo R. Butelman

butelme@rockefeller.edu

Specialty section:

This article was submitted to

Neuropharmacology,

a section of the journal

Frontiers in Pharmacology

Received: 16 November 2015 Accepted: 16 November 2015 Published: 30 November 2015

Citation:

Butelman ER and Kreek MJ (2015)

Corrigendum: Salvinorin A, a

kappa-opioid receptor agonist

hallucinogen: pharmacology and

potential template for nove

pharmacotherapeutic agents in

neuropsychiatric disorders.

Front. Pharmacol. 6:285.

doi: 10.3389/fphar.2015.00285
Reason for Corrigendum:

In the original review, we placed an incorrect citation in the following sentence:

"Also, salvinorin A can act as a "punisher" to self-administration of cocaine or a short-acting MOPr agonist in primates (when given contingently; Whitfield et al., 2015).”

The correct sentence and citation are as follows:

"Also, salvinorin A can act as a "punisher" to self-administration of cocaine or a short-acting MOPr agonist in primates (when given contingently; Freeman et al., 2014).”

The authors apologize for the mistake. This error does not change the scientific conclusions of the review.

\section{REFERENCES}

Freeman, K. B., Naylor, J. E., Prisinzano, T. E., and Woolverton, W. L. (2014). Assessment of the kappa opioid agonist, salvinorin A, as a punisher of drug self-administration in monkeys. Psychopharmacology (Berl.) 231, 2751-2758. doi: $10.1007 / \mathrm{s} 00213-014-3436-2$

Conflict of Interest Statement: The authors declare that the research was conducted in the absence of any commercial or financial relationships that could be construed as a potential conflict of interest.

Copyright $\odot 2015$ Butelman and Kreek. This is an open-access article distributed under the terms of the Creative Commons Attribution License (CC BY). The use, distribution or reproduction in other forums is permitted, provided the original author(s) or licensor are credited and that the original publication in this journal is cited, in accordance with accepted academic practice. No use, distribution or reproduction is permitted which does not comply with these terms. 